\title{
Pengaruh Kualitas Layanan Dan Harga Terhadap Minat Beli Jasa Go-Jek
}

\author{
Aptaguna, A. ${ }^{1}$, Pitaloka, E. ${ }^{1}$ \\ ${ }^{1}$ Program Studi Manajemen, Universitas Pembangunan Jaya, anggaaptaguna@gmail.com \\ ${ }^{2}$ Program Studi Manajemen, Universitas Pembangunan Jaya, oka@upj.ac.id
}

\begin{abstract}
The purpose of this study is to analyze the effect of service quality and price on purchase intention of GO-JEK GO-ride in South Tangerang. GO-JEK is a mobile app-based business that provides service to all transportation, delivery, lifestyle and payment services. In this study, 100 college students were selected by random sampling as respondents. Data resulted from research questionnaire, were analyzed by multiple regression analysis. Results from this study showed that the quality of service has significant and positive effect on purchase intention of GO-JEK GO-ride. However price didn't have a significant impact on customers' purchase intention of GO-JEK ride.
\end{abstract}

Keywords : service quality, price, purchase intention, GO-JEK

\begin{abstract}
Abstrak : Penelitian ini bertujuan menganalisa dampak kualitas pelayanan dan harga terhadap minta beli GO-JEK. GO-JEK adalah jasa transportasi berbasis aplikasi online. Pada penelitian ini layanan GO-JEK dikhususkan pada layanan GO-ride di kalangan mahasiswa/i yang berdomisili di Tangerang Selatan. Responden penelitian ini adalah 100 mahasiswa yang dipilih secara acak (random sampling). instrumen penelitian yang digunakan adalah kuesioner. Data dari kuesioner yang sudah diisi kemudian diolah dengan teknik regresi linier berganda. Hasil penelitian menunjukan bahwa variabel kualitas layanan berpengaruh secara signifikan terhadap minat beli jasa GO-JEK GO-ride. Sedangkan variabel harga tidak berpengaruh secara signifikan terhadap minat beli jasa GO-JEK GO-ride.

Kata Kunci : kualitas layanan, harga, minat beli, GO-JEK
\end{abstract}

\section{LATAR BELAKANG}

Pada era globalisasi saat ini begitu banyak inovasi, sarana dan fasilitas yang dapat digunakan oleh perusahaan dalam memasarkan atau menarik minat konsumen salah satunya adalah dengan memanfaatkan aplikasi online. Hal ini juga dilakukan oleh perusahaan pendatang baru yang bergerak dibidang jasa transportasi yaitu GO-JEK. Perusahaan penyedia layanan ojek ini memanfaatkan saranan teknologi yang jaringan yaitu internet dalam melayani pelanggan. Pelanggan melakukan pemesanan dengan membuat aplikasi GO-JEK sarana ini juga digunakan oleh GO-JEK dalam memasarkan jasa mereka kepada para konsumen.

Salah satu tujuan dari aktivitas pemasaran adalah untuk meningkatkan minat beli yaitu sesuatu diperoleh dari proses belajar dan proses pemikiran yang yang membentuk suatu persepsi. Minat beli ini menciptakan suatu motivasi yang terus terekam dalam benaknya dan menjadi suatu keinginan yang sangat kuat yang pada akhirnya ketika seorang konsumen harus memenuhi kebutuhannya akan mengaktualisasikan apa yang ada didalam benaknya itu (Oliver, 2006).

Pada penelitian Saidani dan Arifin (2012), kualitas produk, kualitas pelayanan dan kepuasan konsumen mempengaruhi 
minat beli. Kualitas pelayanan dipandang sebagai salah satu komponen yang perlu diwujudkan oleh perusahaan, karena memiliki pengaruh untuk mendatangkan konsumen baru dan dapat mengurangi kemungkinan pelanggan lama untuk berpindah keperusahaan lain.

Dalam upaya meningkatkan minat beli, harga juga berperan dalam mempengaruhi minat konsumen akan suatu produk. Pada penelitian Sundalangi, Mandey dan Jorie (2014), Kualitas produk, daya tarik iklan dan potongan harga secara bersama-sama berpengaruh terhadap Minat beli konsumen untuk mengkonsumsi Pizza Hut. Harga adalah sesuatu yang harus diberikan oleh konsumen untuk mendapatkan keunggulan yang ditawarkan oleh bauran pemasaran perusahaan.

Bagi pelanggan harga merupakan hal yang penting karena mampu membuat pelanggan dari pasar industri memperoleh keuntungan. Produk yang mampu memberikan keuntungan, harga jual yang kompetitif dan skema pembayaran yang lunak akan memungkinkan pengguna memperoleh margin keuntungan yang lebih tinggi. Harga merupakan salah satu faktor penentu dalam pemilihan merek yang berkaitan dengan keputusan membeli konsumen. Ketika memilih diantara merek-merek yang ada, konsumen akan mengevaluasi harga secara absolut tetapi dengan membandingkan beberapa standar harga sebagai referensi untuk melakukan pembelian.

GO-JEK adalah perusahaan yang memimpin revolusi industri transportasi ojek. GO-JEK bermitra dengan para pengendara ojek berpengalaman di Jakarta meliputi area JABODETABEK, Bandung, Bali \& Surabaya dan menjadi solusi utama dalam pengiriman barang, pesan antar makanan, berbelanja dan berpergian di tengah kemacetan. GO-JEK menggunakan aplikasi online dalam pemesanan jasa GOJEK, yang memudahkan para pelanggan memesan atau menggunakan pelayanan jasa. Saat ini perkembangan GO-JEK sudah sangat pesat dengan banyaknya armada atau kendaraan yang beratribut GO-JEK. GO-JEK juga memberikan layanan GO-drive (taksi online), dan jasa perwatan kecantikan dan kebersihan (GOglam dan GO-clean).

Layan GO-JEK khususnya GO-ride cukup banyak digunakan berbagai kalangan, termasuk para mahasiswa/i yang tinggal di Tangerang Selatan. Tangerang Selatan dianggap dapat mewakili kota besar di provinsi Banten. Dan populasi mahasiswa/i di Tangsel cukup banyak baik yang berkampus di sekitar wilayah Tangsel maupun Jakarta. Dari survey prapenelitian diketahui bahwa mahasiwa/i tertarik menggunakan layanani ini karena cukup praktis. Pada penelitian ini peneliti mengkaji fenomena penggunaan jasa GOJEK layanan GO-ride (ojek) dikalangan mahasiswa/i yang berdomisili di tangerang selatan.

\section{Rumusan Masalah}

1. Adakah pengaruh antara kualitas pelayanan dan harga terhadap minat beli?

2. Seberapa besar pengaruh kualitas pelayanan terhadap minat beli?

3. Seberapa besar pengaruh harga terhadap minat beli?

\section{Tujuan Penelitian}

1. Untuk mengetahui pengaruh kualitas pelayanan serta harga terhadap minat beli

2. Untuk mengetahui berapa besar pengaruh kualitas pelayanan terhadap minat beli

3. Untuk mengetahui berapa besar pengaruh harga terhadap minat beli

\section{LANDASAN TEORI Kualitas Layanan}

Kualitas merupakan suatu kondisi dinamis yang berpengaruh dengan produk, jasa, manusia, proses dan lingkungan yang memenuhi atau melebihi harapan (Tjiptono, 2001). Sehingga definisi kualitas pelayanan dapat diartikan sebagai upaya pemenuhan kebutuhan dan keinginan konsumen serta ketepatan 
penyampaiannya dalam mengimbangi harapan konsumen (Tjiptono, 2007). Kualitas pelayanan (service quality) dapat diketahui dengan cara membandingkan persepsi para konsumen atas pelayanan yang nyata-nyata mereka terima/peroleh dengan pelayanan yang sesungguhnya mereka harapkan/inginkan terhadap atribut-atribut pelayanan suatu perusahaan. Jika jasa yang diterima atau dirasakan (perceived service) sesuai dengan yang diharapkan, maka kualitas pelayanan dipersepsikan baik dan memuaskan, jika jasa yang diterima melampaui harapan konsumen, maka kualitas pelayanan dipersepsikan sangat baik dan berkualitas. Sebaliknya jika jasa yang diterima lebih rendah daripada yang diharapkan, maka kualitas pelayanan dipersepsikan buruk.

Menurut Kotler (2007) definisi pelayanan adalah setiap tindakan atau kegiatan yang dapat ditawarkan oleh suatu pihak kepada pihak lain, yang pada dasarnya tidak berwujud dan tidak mengakibatkan kepemilikan apapun. Produksinya dapat dikaitkan atau tidak dikaitkan pada satu produk fisik. Pelayanan merupakan perilaku produsen dalam rangka memenuhi kebutuhan dan keinginan konsumen demi tercapainya kepuasan pada konsumen itu sendiri. Kotler juga mengatakan bahwa perilaku tersebut dapat terjadi pada saat, sebelum dan sesudah terjadinya transaksi. Pada umumnya pelayanan yang bertaraf tinggi akan menghasilkan kepuasan yang tinggi serta pembelian ulang yang lebih sering. Kata kualitas mengandung banyak definisi dan makna, orang yang berbeda akan mengartikannya secara berlainan tetapi dari beberapa definisi yang dapat kita jumpai memiliki beberapa kesamaan walaupun hanya cara penyampaiannya saja biasanya terdapat pada elemen sebagai berikut:

1. Kualitas meliputi usaha memenuhi atau melebihkan harapan pelanggan.

2. Kualitas mencakup produk, jasa, manusia, proses dan lingkungan
3. Kualitas merupakan kondisi yang selalu berubah.

Dimensi kualitas pelayanan menurut Kotler (2007)adalah sebagai berikut:

a. Tangibles (bukti langsung), meliputi penampilan fisik dan perlengkapan dengan indikator:

1) Kebersihan, kerapian dan kenyamanan ruangan.

2) Penataan ruang tunggu dan ruang periksa kesehatan pasien.

3) Kesiapan dan kebersihan alat-alat yang dipakai.

b. Reliability (keandalan), yaitu kemampuan memberikan pelayanan yang dijanjikan dengan akurat dan memuaskan dengan indikator:

1) Prosedur penerimaan pasien yang cepat dan tepat.

2) Pelayanan pemeriksaan, pengobatan dan perawatan yang cepat dan tepat.

c. Responsiveness (daya tanggap), yaitu respon atau kesigapan karyawan dalam membantu pelanggan dan memberikan pelayanan yang cepat dan tanggap dengan indikator:

1) Cepat tanggap menyelesaikan keluhan pasien.

2) Memberikan informasi yang jelas dan mudah dimengerti.

3) Saat dibutuhkan pasien, mampu bertindak dengan tepat dan cepat.

d. Assurance (jaminan), dimensi ini meliputi suatu pengetahuan dan ketrampilan yang dimiliki petugas dalam melayani konsumen. Dimensi ini diukur dengan indikator:

1) Memberikan jaminan kesembuhan.

2) Tidak terjadi komplikasi atau kesalahan.

3) Jadwal pelayanan dijanjikan dengan tepat.

e. Emphaty (empati), meliputi kemudahan dalam melakukan hubungan, komunikasi yang baik, perhatian pribadi, dan memahami kebutuhan pelanggan dengan indikator:

1) Bersikap ramah.

2) Perhatian terhadap keluhan pasien dan keluarga. 
3) Pelayanan kepada semua pasien tanpa memandang status sosial.

Dimensi dan indikator di ataslah yang digunakan sebagai instrumen kuesioner dalam penelitian ini.

\section{Harga Produk}

Menurut Kotler (2007) harga merupakan sejumlah uang yang dibebankan atas suatu produk atau jasa atau jumlah dari nilai yang ditukar konsumen atas manfaat-manfaat karena memiliki atau menggunakan produk atau jasa tersebut. Harga adalah jumlah uang yang dibutuhkan untuk mendapatkan sejumlah kombinasi dari barang beserta pelayanannya.

Jadi harga adalah sejumlah uang yang dibutuhkan atau ditukarkan kekonsumen untuk mendapatkan atau memiliki suatu barang yang memiliki manfaat serta penggunaannya.

Indikator yang mencirikan harga menurut Kotler yaitu:

1. Keterjangkauan harga.

2. Kesesuaian harga dengan kualitas produk.

3. Daya saing harga.

4. Kesesuaian harga dengan manfaat produksi.

5. Harga mempengaruhi daya beli beli konsumen.

6. Harga dapat mempengaruhi konsumen dalam mengambil keputusan.

Ke-enam indikator di atas disusun menjadi instrumen kuesioner dalam penelitian ini untuk variabel harga.

\section{Minat Beli}

Minat beli adalah sesuatu diperoleh dari proses belajar dan proses pemikiran yang yang membentuk suatu persepsi. Minat beli ini menciptakan suatu motivasi yang terus terekam dalam benaknya dan menjadi suatu keinginan yang sangat kuat yang pada akhirnya ketika seorang konsumen harus memenuhi kebutuhannya akan mengaktualisasikan apa yang ada didalam benaknya itu Oliver (2006).
Minat beli merupakan bagian dari komponen perilaku dalam sikap mengkonsumsi. Menurut Kinnear dan Taylor dalam Tjiptono (2007), minat beli adalah tahap kecenderungan responden untuk bertindak sebelum keputusan membeli benar-benar dilaksanakan. Menurut Oliver (2006) efek hierarki minat beli digunakan untuk menggambarkan urutan proses munculnya keyakinan (beliefs). Sikap (attitudes) dan perilaku pengetahuan kognitif yang dimiliki konsumen dengan mengaitkan atribut, manfaat, dan obyek (dengan mengevaluasi informasi), sementara itu sikap mengacu pada perasaan atau respon efektifnya. Sikap berlaku sebagai acuan yang mempengaruhi dari lingkungannya.

Indikator Minat Beli menurut Tjiptono (2007), minat beli dapat diidentifikasi melalui indikator-indikator sebagai berikut:

1. Minat transaksional, yaitu kecenderungan seseorang untuk membeli produk.

2. Minat refrensial, yaitu kecenderungan seseorang untuk mereferensikan produk kepada orang lain.

3. Minat preferensial, yaitu minat yang menggambarkan perilaku seseorang yang memiliki prefrensi utama pada produk tersebut. Preferensi ini hanya dapat diganti jika terjadi sesuatu dengan produk prefrensinya.

4. Minat eksploratif, minat ini menggambarkan perilaku seseorang yang selalu mencari informasi mengenai produk yang diminatinya dan mencari informasi untuk mendukung sifat-sifat positif dari produk tersebut.

Indikator minat beli di atas disusun menjadi instrumen kuesioner dalam penlitian ini.

\section{Penelitian sebelumnya}

Pada penelitian Saidani dan Arifin (2012), kualitas produk, kualitas pelayanan dan kepuasan konsumen mempengaruhi minat beli. Terbukti secara empiris 
kualitas produk dan kualitas layanan berpengaruh terhadap kepuasan konsumen dan minat beli ulang. Penelitian Sundalangi, Mandey dan Jorie (2014) menunukan Kualitas produk, daya tarik iklan dan potongan harga secara bersamasama berpengaruh terhadap Minat beli konsumen untuk mengkonsumsi Pizza Hut. Pengaruh yang diberikan oleh variabel tersebut digambarkan dengan $F$ hitung lebih besar dari $\mathrm{F}$ Tabel sehingga dinyatakan berpengaruh secara simultan terhadap Minat beli konsumen untuk mengkonsumsi Pizza Hut.

Penelitian Arslan dan Zaman (2014) mengenai minat beli konsumen di retail store menunjukan citra merek, kualitas peayanan adalah variabel yang mempengaruhi minta beli secara signifikan. Namun variabel harga tidak memiliki pengaruh signifikan terhadap minat beli. Hal ini karena menurut konsumen harga produk-produk yang dijual sudah seusia dengan nilai produk. Konsumen lebih mengtamakan citra merek dan pelayanan dalam pembelian suatu produk.

Nikhashem, et al (2012) melakukan penelitian minat beli pada jasa travel online untuk produk tiket. Hasil penelitian mereka menunjukan kualitas pelayanan (eservice quality), persepsi harga dan iklan menjadi faktor yang berpengaruh signifikan terhadap minat beli. Faktor yang berkontribusi besar tehadap minat beli adalah e-sevice quality dan iklan. Dalam era digital $e$-service quality ternyata tetap memiliki daya tarik bagi pelanggan dan dianggap lebih praktis dibanding jasa penjualan tiket konvensional. Selain itu layanan online dapat menjangkau lebih banyak konsumen karena tidak ada hamabatan goegrafis. Penelitian ini menyarankan perusahaan untuk meningkatkan e-service quality dan frekuensi iklan porduk dalam pelayanan tiket online di berbagai media.

Penelitian dengan topik yag sama juga dialakukan oleh Mirabi, Akbariyeh \& Tahmasebifard (2015). Pada penelitian ini variabel kualitas produk, iklan, dan citra merek berpengaruh secara signifikan terhadap minat beli. Sedangkan variabel harga tidak berpengaruh pada minat beli. Jika kualitas produk memuaskan dan citra merek cukup kuat maka konsumen memiliki kepercayaan terhadap produk tersebut, sehingga harga bukan menjadi pertimbangan utama dalam menentukan pembelian produk tersebut.

Beberapa penelitian terdahulu telah mengkaji faktor-faktor yang mempengaruhi minat beli. Namun sepengetahuan peneliti belum ada penelitian yang mengkaji minat beli pada jasa transportasi online khususnya GOJEK dengan unit analisis mahasiswa di Tangerang Selatan. Hal tersebut menjadi poin originalitas dari penelitian ini.

Berdasarkan kajian penelitian terdahulu di atas, maka kerangka pemikiran dalam penelitian ini adalah sebagai berikut:

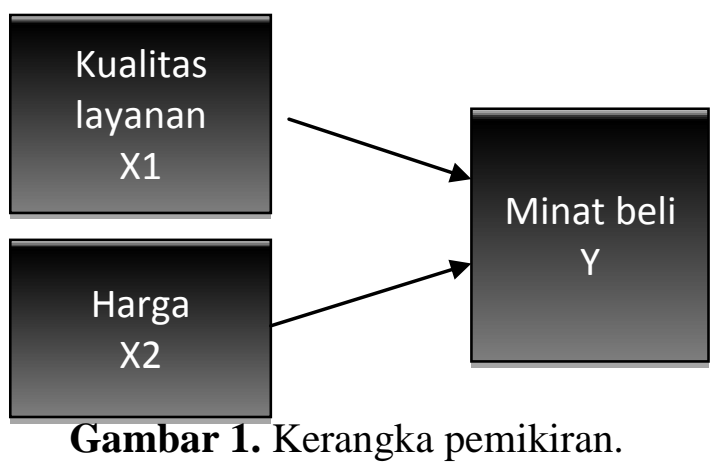

\section{Hipotesis penelitian}

H1 : Kualitas layanan mempengaruhi minat beli

H2 : Harga mempengaruhi minat beli

\section{METODE PENELITIAN}

Objek penelitian ini adalah transportasi publik GO-JEK, GO-JEK adalah salah satu sarana transportasi berbasis motor dengan melalui media online sebagai cara pemesananan. Penelitian ini menggunakan metode penelitian kuantitatif Adalah yang lebih menekankan pada aspek pengukuran secara obyektif terhadap fenomena sosial. Untuk dapat melakukan pengukuran, 
setiap fenomena sosial di jabarkan kedalam beberapa komponen masalah, variabel dan indikator. Pengumpulan data menggunakan data primer Kuesioner yang disebarkan kepada 100 responden mahasiswa/i yang berdomisili di tangerang selatan. Teknik pengambilan sampel dengan random sapling. Penilaian kuesioner menggunakan sakla interval 1-5 semakin besar maka persepsi responden semakin positif terhadap pernyataan dalam kuesioner.

\section{Teknik Analisa Data}

Teknik analisis data multiple linear regression Regresi linear adalah alat statistik yang dipergunakan untuk mengetahui pengaruh antara satu atau beberapa variabel terhadap satu buah variabel. Variabel yang mempengaruhi sering disebut variabel bebas, variabel independen atau variabel penjelas. Variabel yang dipengaruhi sering disebut dengan variabel terikat atau variabel dependen. Instrumen penelitian sebelumnya telah diuji dengan uji validitas pearson product momentum dan reliabilitas dengan cornbach alpha. Hasil uji validitas dan reliabilitas menunjukan bahwa seluruh butir pertanyaan pada kuesionel valid dan riliable. Untuk mengetahui pengaruh antar variabel maka digunakan Uji hipotesis secara simultan dan parsial pada tingkat kepercayaan $95 \%$ $(\mathrm{a}=5 \%)$. uji hipotesis dilakukan dengan mebandingkan nilai signifikansi pada Fstatistik dan t-statistik. Jika nilai signifikansi pada F-statistik dan t-statistik tidak lebih dari 0.05 maka variabel independen memiliki pengaruh yang signifikan terhadap variabel dependen. Jika nilai signifikansi pada F-statistik dan t-statistik lebih besar dari 0.05 maka variabel independen tidak memiliki pengaruh yang signifikan terhadap variabel dependen.

\section{PEMBAHASAN}

Nilai koefisien pelayanan adalah 0.156, artinya setiap kenaikan kualitas layanan sebesar 1 point dengan asumsi variabel lain tetap maka akan meningkatkan minat beli sebesar 0,156 point.

Kualitas layanan berpengaruh terhadap minat beli GO-JEK jenis GO-ride telah memberikan kualitas layanan yang sangat baik seperti atribut yang dibawa dan dikenakan pengendara GO-JEK (GOJEK driver) yang lengkap seperti helm, masker, penutup kepala (untuk pelanggan). Motor yang digunakan GO-JEK juga motor yang nyaman dan aman sesuai standar yang ditetapkan GO-JEK. GO-JEK driver juga dinilai cukup responsive terhadap permintaan pelanggan dan mengetahui rute tujuan pelanggan. GOJEK driver juga dinilai komunikatif dengan pelanggan dan memiliki empati dalam membantu dan melayani pelanggan. Hal-hal tersebut menunjukan pelayanan GO-JEK GO-ride sudah memenuhi kriteria (Bukti Fisik), reliability (Keandalan), Responsiveness (Ketanggapan), Assurance (Jaminan), Empathy (Empati) yang baik. Dengan melakukan peningkatan kualitas layanan dengan baik maka minat beli akan dapat terwujud.

$$
\text { Dengan selalu meningkatkan }
$$

kualitas layanan yang diberikan oleh perusahaan dan konsumen dapat merasakan kualitas dari layanan yang diberikan sehingga konsumen dapat merasakan kepuasaan dari penggunaan layanan jasa yang diberikan ooleh perusahaan. Menurut Mowen dalam Oliver (2006) efek hierarki minat beli digunakan untuk menggambarkan urutan proses munculnya keyakinan (beliefs). Sikap (attitudes) dan perilaku pengetahuan kognitif yang dimiliki konsumen dengan mengaitkan atribut, manfaat, dan obyek (dengan mengevaluasi informasi). Dengan kualitas layanan yang diberikan oleh perusahaan sangat memungkinkan dalam meningkatkan minat beli dari calon konsumen, maka semakin baik kualitas layanan yang diberikan akan semakin meningkatkan minat beli pada konsumen. 
Tabel 1. Uji hipotesis simultan (uji-F)

\begin{tabular}{l}
\hline \multicolumn{7}{|l|}{ ANOVA $^{\mathbf{b}}$} \\
\end{tabular}

Tabel 2. Uji hipotesis parsial (uji-t)

\begin{tabular}{|c|c|c|c|}
\hline & \multirow[b]{2}{*}{ Model } & \multicolumn{2}{|c|}{ Unstandardized Coefficients } \\
\hline & & B & T-sig \\
\hline \multirow[t]{3}{*}{1} & (Constant) & 7.186 & .000 \\
\hline & Pelayanan & .156 & .005 \\
\hline & Harga & -.083 & .424 \\
\hline
\end{tabular}

1. $\mathrm{P}$ value pelayanan $=0,005$. Dengan demikian variabel kualitas layanan mempengaruhi minat beli dengan tingkat keyakinan sebesar 95\%

2. $\mathrm{P}$ value harga $=0,424$. Dengan demikian variabel harga tidak mempengaruhi minat beli pada tingkat keyakinan $95 \%$

Nilai koefisien harga adalah -0.083 artinya setiap kenaikan harga sebesar 1 point dengan asumsi variabel lain tetap maka akan menurunkan minat beli sebesar 0,83 point.

Harga dalam penelitian ini tidak berpengaruh terhadap minat beli. Hal ini mungkin disebabkan oleh kualitas layanan yang sduah baik sehingga membuat pelanggan tidak mempertimbangkan harga. Selain itu karena fenomena ojek online cukup baru, banyak pelanggan yang berminat menggunakan layanan ini karena menginginkan pengalaman baru dalam transportasi umum. Walaupun demikian harga berbanding negatif dengan minat beli. Semakin tinggi harga layanan GOJEK GO-ride maka akan semakin menurun minat beLi terhadap jasa GO-JEK GOride.

\section{KESIMPULAN}

Berdasarkan hasil penelitian dapat disimpulkan bahwa variabel kualitas layan dan harga secara simultan berpengaruh signifikan terhadp minat beli. Variabel kualitas pelayanan secara parsial berpengaruh signifikan terhadap minat beli sedangkan variabel harga tidak berpengaruh secara signifikan terhapa minta beli. Kualitas pelayanan GO-JEK GO-ride menjadi alasan utama yang mendorong minat pelanggan untuk menggunakan jasa GO-ride. Oleh karena itu diharapkan GO-JEK dapat terus mempertahankan kualiatas layanan yang sangat baik kepada pelanggan. 


\section{DAFTAR PUSTAKA}

1. Arslan, M., Zaman, R. 2014. Impact of Brand Image and Service Quality on Consumer Purchase Intention: A Study of Retail Store in Pakistan Research on Humanities and Social Sciences, Vol.4, No.22, 98-106.

2. Kotler, P. 2007. Manajemen Pemasaran. Edisi Keduabelas. Jilid Kesatu. Jakarta : PT. Indeks.

3. Mirabi, V., Akbariyeh, H., Tahmasebifard, H,. 2015, A Study of Factors Affecting on Customers Purchase Intention (Case Study: the Agencies of Bono Brand Tile in Tehran). Journal of Multidisciplinary Engineering Science and Technology (JMEST), Vol. 2 Issue 1,. 267-273.

4. Nikhashemi, S. R., Haque, A., Yasmin, F., Khatib, A., 2012. Service Quality and Consumer Purchasing Intention Toward Online Ticketing: An Empirical Study in Iran. International Conference on Economics, Business Innovation IPEDR vol.38 (2012), 150-154, IACSIT Press, Singapore.

5. Oliver, R. L. 2006. Satisfaction A Behavioral Prespective On The Costumer. Mc. Graw - Hil. New York.

6. Saidani, B., Arifin, S. 2012. Pengaruh Kualitas Produk dan Kualitas Layanan terhadap Kepuasan Konsumen dan Minat Beli Pada Ranch Market. Jurnal Riset Manajemen Sains Indonesia, Vol. 3 No. 1, pp 1-22.

7. Sundalangi, M., Jorie. 2014. Kualitas Produk, Daya Tarik Iklan, Dan Potongan Harga Terhadap Minat Beli Konsumen Pada Pizza Hut Manado.
Jurnal EMBA, Vol.2 No.1 Maret, 313324.

8. Tjiptono, F. 2007. Strategi Pemasaran. Edisi Kedua. Yogyakarta : Andi Ofset. 